\title{
THE SOFT ROCK SOCKETED MONOPILE WITH CREEP EFFECTS - A RELIABILITY APPROACH BASED ON WAVELET NEURAL NETWORKS
}

\author{
PAL OSADZONY W MIĘKKIEJ SKALE Z WPLYWEM PELZANIA - PODEJŚCIE \\ NIEZAWODNOŚCIOWE BAZUJACE NA SIECIACH FALKOWO-NEURONOWYCH
}

\begin{abstract}
In the present study the numerical model of the pile embedded in marl described by a time dependent model, based on laboratory tests, is proposed. The solutions complement the state of knowledge of the monopile loaded by horizontal force in its head with respect to its random variability values in time function. The investigated reliability problem is defined by the union of failure events defined by the excessive horizontal maximal displacement of the pile head in each periods of loads. Abaqus has been used for modeling of the presented task with a two layered viscoplastic model for marl. The mechanical parameters for both parts of model: plastic and rheological were calibrated based on the creep laboratory test results. The important aspect of the problem is reliability analysis of a monopile in complex environment under random sequences of loads which help understanding the role of viscosity in nature of rock basis constructions. Due to the lack of analytical solutions the computations were done by the method of response surface in conjunction with wavelet neural network as a method recommended for time sequences process and description of nonlinear phenomenon.
\end{abstract}

Keywords: reliability, pile, marl, creep, wavelet neural network, response surface

W niniejszym studium zaprezentowany jest problem pojedynczego pala osadzonego w miękkiej skale, zastosowano wiskoplastyczny model materiału bazujący na wynikach badań laboratoryjnych zespołu z Uniwersytetu Montenegro. Rozwiązanie uzupełnia stan wiedzy dla pali obciążonych poziomą siłą w głowicy zmienną w sposób losowy w czasie. Badany problem niezawodności został określony przez sumę zdarzeń - awarii - zdefiniowanych jako przekroczenie maksymalnie dopuszczalnego poziomego przemieszczenia głowicy pala niezależnie $\mathrm{w}$ wszystkich stanach obciążenia. Zastosowano program metody elementów skończonych, ABAQUS, do budowy trójwymiarowego modelu z dwuwarstwowym wiskoplastycznym modelem dla margla. Parametry mechaniczne modelu zarówno w części plastycznej i reologicznej zostały skalibrowane na podstawie wyników badań laboratoryjnych wykonanych na przestrzeni ostatnich czterech lat na próbkach z jednorodnego złoża margla w Montenegro. Ważnym aspektem problemu jest analiza niezawodności pojedynczego pala dla złożonego mechanicznie środowiska w ramach sekwencji

* WROClAW UNIVERSITY OF TECHNOLOGY.

** UNIVERSITY OF MONTENEGRO. E-MAIL: zvonko@ac.me, sloboz@hotmail.com.

1 CORRESPONDING AUTHOR: E-MAIL: janusz.kozubal@pwr.edu.pl 
losowych obciążeń. Przedstawione zadanie pozwala dostrzec istotę lepkiej części modelu. Ze względu na brak rozwiązań analitycznych oraz długotrwałość procesu obliczeniowego obliczenia niezawodnościowe przeprowadzono metodą powierzchni odpowiedzi bazując na sieciach falkowo-neuronowych. Sieć poprzez nadanie jej struktury rejestru została dostosowana do opisu procesu o nieliniowym charakterze zjawiska i dla obciążeń zmiennych w czasie.

Słowa kluczowe: niezawodność, pal, margiel, pełzanie, sieci falkowo-neuronowe, powierzchnia odpowiedzi

\section{Introduction}

The objectives of the paper are single piles subjected to lateral loads embedded in complex environment. The monopiles are commonly used as supporting structures for power transmission lines, wind power generators and for transpose of horizontal forces from arcs of bridges, where the horizontal forces are significant. Different technologies are used for embedding of piles into the rock bed. The main aim of this paper is to present modelling of the rheological material of substrate in classical 3D finite element method (FEM) program as tool to a reliability assessment. The probability of malfunction of piles on the base of serviceability limit state was considered. This article is based on a wide program of laboratory creep tests of soft rock - marl specimens prepared by Tomanovic (2006) and Zivaljevic \& Tomanovic (2014). A rheological model of soft rocks was formulated including time dependent viscosity deformations. A number of specific rheological material coefficients that were considered required a special method of numerical model calibration based on a special optimization procedure. This task is further complicated by the fact that, on the one hand, a mathematical model is required so as to encompass as many material properties as possible and, on the other hand, the number of parameters and material constants quantifying these properties is limited by actual possibility to evaluate these parameters, that is, material constants, and this either by measurements 'in situ' or by specimen testing in laboratory (Nowakowski (2012) and Kwaśniewski (2013)). The rheological modelling of the rock mass is an extremely complex problem and, for that reason, some approximations have to be made during formulation of the mathematical model and optimization process, regardless of its complexity (Wallner (1983), corrected by Tomanovic (2006)). The material was used to construct 3D model of the marl socketed pile. An overview of the computational methods dealing with laterally loaded piles is given in the book by Reese \& Van Impe (2001) as well as in the papers by Reese $\&$ Welch (1975), Randolph (1981) and Ismael (1990). However, taking into account relatively high sensitivity of pile bearing capacity and displacements to the variation of soil properties as well as loading fluctuations, a deterministic analysis may occur inadequate. This shortcoming can be overcome by implementing probabilistic methods. In most cases, from the point of view of the designer, the limiting conditions that govern the design procedures are most significant (Majcherczyk, Niedbalski and Kowalski (2012)). In the case of laterally loaded piles the horizontal displacement at the pile's head must not exceed an allowable value. One of the important contributions to consideration of this problem in conjunction with the probabilistic approach were presented in the paper by Jiang et al. (2014), Kamruzzaman, Leonard \& Lye (2008) and Jakubowski (2011). Since sixties, several numerical procedures have been developed to deal with uncertainties and variability in engineering applications (FORM, SORM, Monte Carlo simulations, neural networks, fuzzy sets, response surface method, etc.). The main goal is to estimate the reliability index $\beta$ related to designing parameters (Ditlevsen 1979), such as the limit load or serviceability 
states. To this end, the response surface method (RSM) has been largely applied (Bauer et al., 2012, 2013; Bauer \& Puła, 2000). This method works efficiently when applied to physical problems solved by means of numerical methods and whenever few variables are taken into account.

\section{The soft rock material and description and the model}

\subsection{Experimental data - soft rock creep tests}

Tested soft rock is a natural cement marl of Middle Miocene age with rating as poor rock (IV) after Bieniawski's (1989) Rock Mass Rating Classification, originating in the pit 'Potrlica' of the coal mine in Pljevlja, in upstate Montenegro. Tested marl, according to its chemical composition contains $\mathrm{CaCO}_{3} 50.05 \%, \mathrm{SiO}_{2} 17.60 \%$. Average uniaxial strength of the material is about $12 \mathrm{MPa}$. Creep tests were conducted on three groups of prismatic specimens with dimensions $0.15 * 0.15 * 0.40 \mathrm{~m}$. Loads were applied perpendicular to bedding planes and maintained using six mechanical devices with the 'dead weight loads' and systems of levers were used for loading and maintaining constant forces over time. During the tests, each device was controlled for variation of forces, and vertical and horizontal deformations were measured at all four sides of the prismatic specimens. The procedure is described in detail by Tomanovic (2006). The procedures were resource and time consuming.

\subsection{Description of the two-layered viscoplasticity model}

The model presented in this article has two parts for response with plasticity and viscosity, and represents a simpler version of Wallner's model (Tomanovic, 2006). The elastic part of the response for both branches is specified by a linear elasticity. In Fig. 1 the one-dimensional

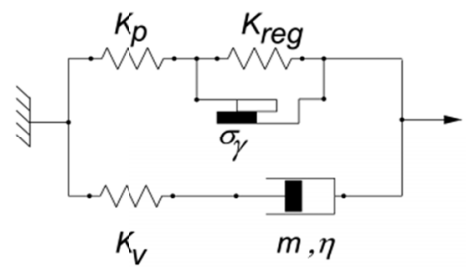

Fig. 1. The one-dimensional idealization of two-layer viscoplasticity model (symbols are presented in the text); an arrow is simplified force

idealization is presented, the ratio of the elastic modulus of the elastic-viscous network (Maxvell's body) $K_{v}$ to the total modulus $\left(K_{v}+K_{p}\right)$ of elasticity is given:

$$
f=\frac{K_{v}}{K_{v}+K_{p}}
$$

for isotropic elastic properties were defined, the Poisson's ratios are the same in both branches. On the other hand, if anisotropic elasticity is defined, the same type of anisotropy holds for both 
networks (Abaqus 6.9 Analysis User's - Manual Chapter 19). The viscosity is described by power-law model corresponding with strain hardening environment as follows:

$$
\dot{\varepsilon}^{c r m}=A \tilde{q}^{n} t^{m}
$$

where:

$$
\dot{\varepsilon}^{c r m}=\sqrt{\frac{2}{3} \dot{\varepsilon}^{c r}: \dot{\varepsilon}^{c r}}
$$

is the uniaxial equivalent creep strain rate, $\tilde{q}$ is the uniaxial Mises' equivalent deviatoric stress, $t$ is the total time and $A, n, m$ are parameters, with the additional constrains: $A>0, n>0,-1<m<0$. The form of 'strain hardening' appropriate to the power-law is:

$$
\dot{\varepsilon}^{c r m}=\left(A \tilde{q}^{n}(m+1) \varepsilon^{c r m}\right)^{\frac{1}{1+m}}
$$

the parameters for best fitting of experimental data are $A=3 * 10^{-7}, n=1, m=-0.8, f=0.5$, Poisson's ratio 0.3 and for only elastic part Young's modulus 1.0 MPa. On Fig. 2a the comparison between experiments and numerical results (model property calibration) are presented where were provided creep tests as in Fig. $2 \mathrm{~b}, 2 \mathrm{c}$ with constant value of pressure $p=\{2.0 ; 4.0 ; 6.0\} \mathrm{MPa}$.

The plasticity element is based on a Mises' yield condition with the hardening $K_{r e g}$. The parameters for plasticity branch were taken from the short time results.
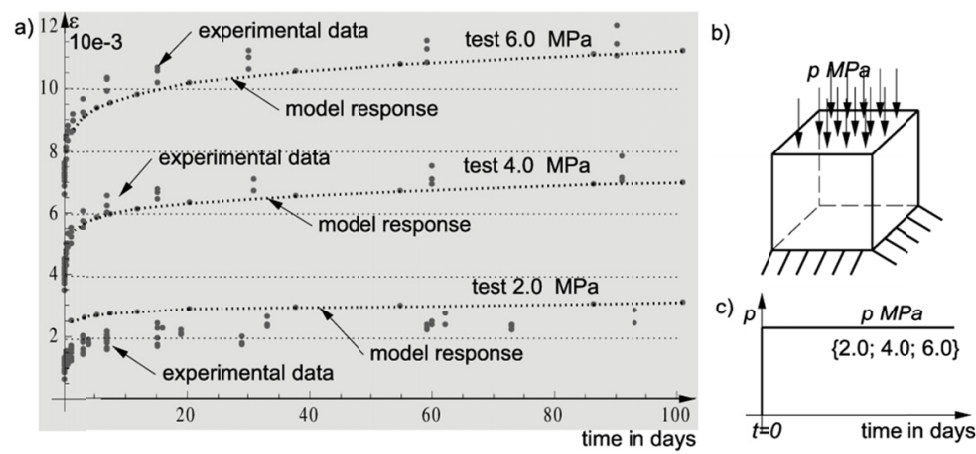

Fig. 2. Creep test scheme, and calibration results a) graph presents strains for calibration results (lines) with points from experimental data, b) the scheme of experiment, c) during of each experiment the value of force (pressure) was constant

Figure $3 \mathrm{~b}$ best illustrates this interesting phenomenon. The task shows the dependence of the vertical deformation on the history of loading (constant loads in three equal periods). The same model as the previous one has been used for calibration. All possible combinations of vertical load from a set $\mathbf{p}=\{1,2,3\} \mathrm{MPa}$ are presented on Fig. 3c. For all these combinations were this same average loads $\mathbf{E}[\mathbf{p}]$ and variances $\operatorname{Var}[\mathbf{p}]$. Time common to all sets was one year. Each load was attached to $1 / 3$ of the year. In the task result was illustrated the effects of using two layered model for soft rocks Fig. 3a. Where for the same average loads specimen reached different values of vertical deformation. 
Fig. 3a shows results of multistage loads (Fig. 3c) of a test cube (Fig. 3b). The time influence has an important role to reach a total strain in the material.
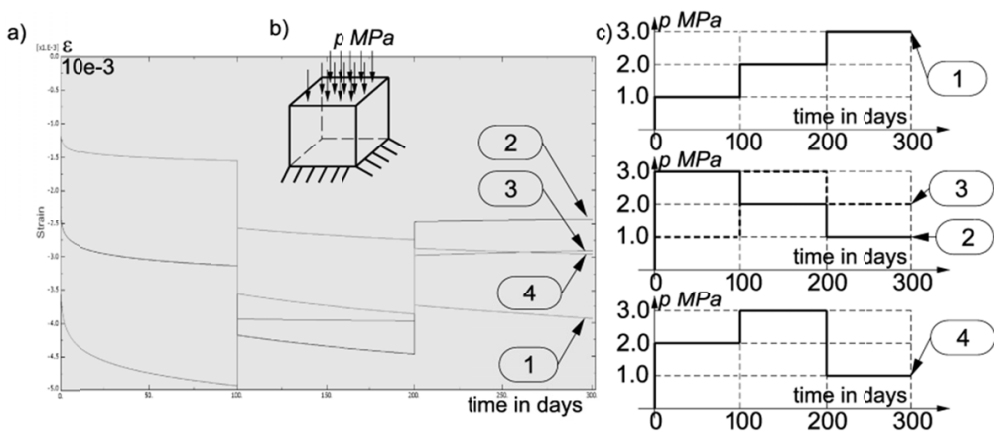

Fig. 3. Results for creep test of a prismatic specimens with visco-plasticity material: a) strain in four tests, b) the scheme of test, c) paths of loads

\subsection{Numerical model}

The model presented in Fig. 4 of the monopile socketed in soft rock is composed of three elements: concrete pile modeled by ideal elastic material, soft rock bed around pile and rigid board which was on a pile head. The forces are devolved by analytical rigid board. Connections between the elements are modeled as ties constraints.

The values of forces were compatible with vectors in Fig. 4c. The boundary conditions were restricted in each side of soft rock bed and they were fixed in all directions with adequate conditions on symmetry plane (Fig. 4d). Solution was conducted under time dependent regime of calculation excluding gravity influence.

a)

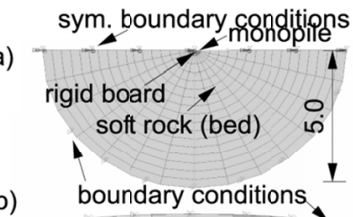

b)

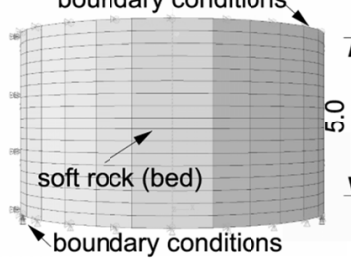

c) $\mathrm{H} \uparrow$ rigid goard

monopile horizontal forc

d)
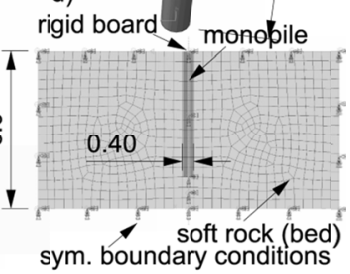

Fig. 4. Numerical model of embedded pile: a) top view on the model, b) rear view on the model, c) front view on symmetry plane of the model, d) extracted view on the pile with cap

All elements and types of material are listed in table 1. The detailed descriptions of two layered model used for soft rock is presented thereafter. 
The elements and materials types in numerical task

\begin{tabular}{|c|c|c|c|}
\hline Part & Element type 1 & Element type 2 & Material \\
\hline Soft rock (bed) & C3D8R & - & $\begin{array}{c}\text { two layered } \\
\text { (plasticity and viscosity }\end{array}$ \\
\hline Rigid board & R3D4 & R3D3 & analytical rigid \\
\hline Pile & C3D8 & C3D6 & elastic \\
\hline C3D8R & 8-node linear br & aced integration & urglass control \\
\hline C3D6 & 6-node linear tri & prism & \\
\hline C3D8 & 8-node linear br & & \\
\hline R3D4 & 4-node, bilinear q & eral & \\
\hline R3D3 & 3-node, triangula & & \\
\hline
\end{tabular}

The deterministic solution is a base for further probabilistic assessment. The result was achieved on soft rock calibrated viscoplasticity model in a numerical task showed on Fig. 1. Horizontal displacements were analyzed in each stage of loading by one horizontal force with constant values in all stages. The resulting displacements are illustrated in Fig. 5. The scheme of loads in different periods is presented in Fig. 5c. Graphical results of strains and displacements of pile head in the time are decomposed to viscosity and plastic strains. Values of horizontal forces $f_{i}$ were constant in four periods $t_{i}$ of life of object as $\left\{f_{i}, t_{i}\right\}$ where $i=\{1,2,3,4\}:\{\{0.8,150\}$, $\{1.2,100\},\{1.8,50\},\{2.4,24\}\}$, where forces are in $\mathrm{MN}$ (this values are identical in both parts of symmetrical model) and time in days.

a)

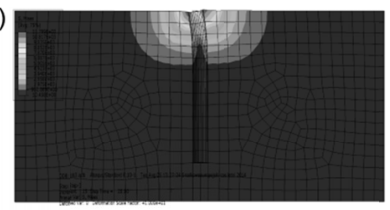

b)

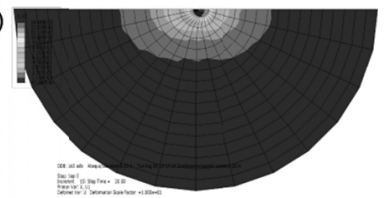

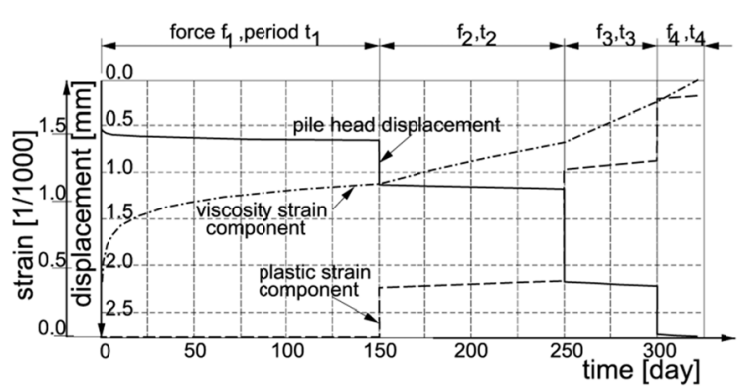

Fig. 5. The example of deterministic results a) top view b) front view on symmetry plane, c) displacement details of pile head with viscosity and plastic strain components

\section{Reliability problem}

\subsection{Response surface method - method for approximating the limit state}

The explicit form of the limit state functions, especially in viscosity three dimensional tasks presented earlier, is seldom available. Thus, deterministic values of Head Pile Displacements (HPD) are usually carried out by means of numerical methods (e.g. DDA, DEM or FEM) whereas the response surface method (RSM) is commonly used to perform reliability-based analyses. 
The RSM was used for the reliability analyses of structural engineering problems in nineties by Faravelli (1989) and Engelund \& Rackwitz (1992). Since then on, it has been applied to numerous fields of knowledge and it is exhaustively described e.g. in several monographs (e.g. Box \& Draper, 1996).

In general, this method consists on approximating an unknown function through an assigned known function. The known function can be drawn from the results of numerical computations with respect to steady state, where periods are the additional variables. In this case, a relationship between loads or model parameters that are pairs of input data as $\left\{\left\{x_{1}, t_{1}\right\},\left\{x_{2}, t_{2}\right\}, \ldots,\left\{x_{\mathrm{N}}, t_{\mathrm{N}}\right\}\right\}$, and the output data $y=f\left(\left\{\left\{x_{1}, t_{1}\right\},\left\{x_{2}, t_{2}\right\}, \ldots,\left\{x_{\mathrm{N}}, t_{\mathrm{N}}\right\}\right\}\right)$ is defined. Hence, a cumbersome numerical procedure is replaced by a simple analytical relationship.

Accordingly, the approximated $H P D$ function is described by the following non linear regression model:

$$
H P D=f(\{\mathbf{x}, \mathbf{t}\}, \mathbf{b})+e r r
$$

where $\{\mathbf{x}, \mathbf{t}\}$ are $N$ sets of stages variables $\mathbf{x}$ after compared $\mathbf{t}$ periods, $\mathbf{b}$ is a vector of $k$ unknown parameters of the regression model, $f$ is the function and $e r r$ is a random variable describing the estimation error.

The components of the vector $\mathbf{b}$ are determined by minimizing the sum of the squared differences between the given and the predicted $H P D_{i}$ values:

$$
\operatorname{Var}(H P D)=\sum_{i}^{n}\left(H P D_{i}(\{\mathbf{x}, \mathbf{t}\})-\overline{H P D}_{i}(\{\mathbf{x}, \mathbf{t}\})\right)^{2}
$$

where $\{\mathbf{x}, \mathbf{t}\}$ represents the vector of the input data, $\overline{H P D}_{i}(\{\mathbf{x}, \mathbf{t}\})$ are the approximated values according to Eq. (6) and $H P D_{i}(\{\mathbf{x}, \mathbf{t}\})$ are the known calculated values.

\subsection{Wavelet neural networks}

The wavelet neural networks WNN approach as well as the fuzzy logic (Gaige et al., 2013) has been employed to deal with uncertainties in soils and rocks where several variables shall be taken into account (Torno et al., 2012). In this paper, the wavelet neural network method has been used to derive the response surface equation. According to the authors experience in structures based on neural network scheme has been efficiently applied to geotechnical problems, providing resistant approximates of implicit functions by Bauer et al. (2012), Kozubal et al., (2014). The comparisons between WNN and, wide used by engineering applications, radial basis function RBF gave more efficient results in time of calculation aspect for WNN.

Under fundament of WNN there are special functions named wavelets from wide class developed by many authors as Percival and Walden (2000), Veitch (2005). A wavelet is a function $\varphi(u)$, which may be called a basic mother wavelet function, provided it fulfills the following three conditions after Veitch (2005):

- The integral of $\varphi(u)$ is zero:

$$
\int_{-\infty}^{\infty} \varphi(u) d u=0
$$


- The integral of the square of $\varphi(u)$ is unity:

$$
\int_{-\infty}^{\infty} \varphi^{2}(u) d u=1
$$

- Admissibility condition:

$$
C_{\varphi} \equiv \frac{\int_{0}^{\infty}|\varphi(f)|^{2} d f}{f}, \text { statisfies } 0<C_{\varphi}<\infty
$$

Two general types of wavelet functions that are in use are discrete and continuous from the time aspect. If translation and scale for a wavelet mother function is made, by a translation factor $\tau$, and the scale factor $a$, that a mother wavelet function is assumed:

$$
\Psi_{a, \tau}(u)=\sqrt{a} \varphi\left(\frac{u-\tau}{a}\right), a>0, \tau \in \mathbb{R}
$$

WNN has got a topology which is based on neural network with one hidden layer, where a signal transfer function in neurons of a hidden layer is the mother wavelet function in place of hyperbolic tangent function. The network topology is shown in Figure 6. In the scheme vector $\left\{x_{i}, t_{i}\right\}$ is the input signal, $\mathbf{u}$ is the output vector and $\Psi$ is a set of mother functions. The addition of the $\mathbf{y}$ vector is to deal with functions whose mean is nonzero (since the wavelet function $\psi(u)$ is zero mean). The $\mathbf{y}$ value is a substitution for the scaling function.

For the input signal sequence the output is calculated as:

$$
d_{i}=y_{i}+\sum_{j=1}^{K} \Psi_{a_{j}, \tau_{j}} \sum_{n=1}^{N}\left(w_{n} x_{n}+w_{N+n} t_{n}\right), i=1,2, \ldots, M
$$

and presented in Fig. 6a. In some tasks it is more convient to write a network with a structure that resembles a row, as presented in Fig. 6b, where single elements marked as WN1 ... WN6 are a subnet associated with the architecture in Fig. 6 a.

a)

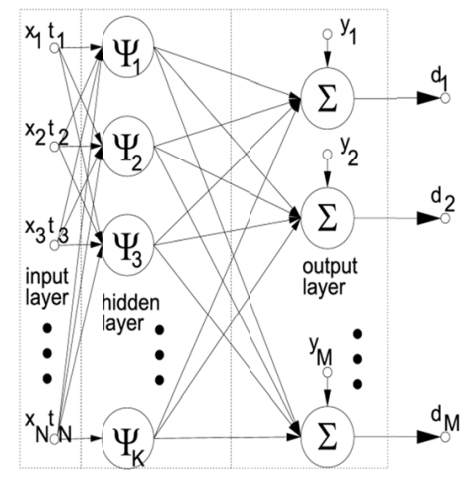

b)

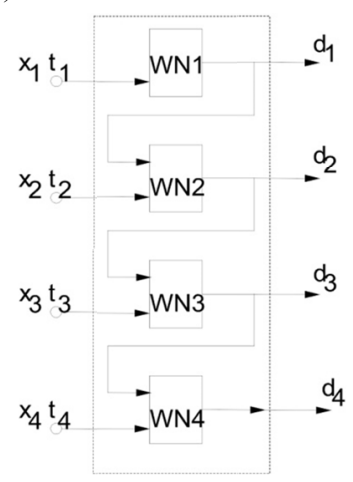

Fig. 6. The architecture of a) wavelet neural network with an one hidden layer (WN) by Veitch (2005), b) set of wavelet neutral networks (WN1 ... WN4) connected in a raw register 
Hereafter, the WNN with the Gaussian type mother basis functions of activation was used:

$$
\varphi(u)=\frac{u}{\sqrt{2 \pi}} e^{-0.5 u^{2}}
$$

and Morlet, after Gaige et al. (2013)

$$
\varphi(u)=\cos (1.75 u) \mathrm{e}^{-0.5 u^{2}}
$$

In order to approximate a continuous function, three-layered WNN with one hidden layer, containing in stepped calculation for 15 to 40 wavelons in hidden layer shall be used to get satisfactory results. This type of WNN is able to approximate those functions of independent variables (commonly providing an acceptable accuracy) characterized by a wide range of variations for proposed random distribution. In the next section a three-layered WNN has been used and four input variables in the first layer are assumed as sets of independent random variables. The unknown vector of weights and factors was determined by the Levenberg-Marquardt's (Marquardt 1962) algorithm.

\subsection{Limits of safety}

The main documents that have been drawn on reliability design based in Europe: Standard ISO 2394 (1998) 'General Principles on Reliability of Structures', the probabilistic model code with guidance on the modeling of the random variables in structural engineering developed by the Joint Committee on Structural Safety (JCSS 2001), the structural Eurocodes. Suggestions regarding values of $\beta$ for different geotechnical engineering problems given by the documents are shown in Table 2.

TABLE 2

Target reliability indices for the different reference periods in terms of safety costs (JCSS 2001, EN 1990,

\begin{tabular}{|c|c|c|c|c|}
\hline Codes & \multicolumn{4}{|c|}{ Consequences } \\
\hline $\begin{array}{l}\text { EN } 1990 \\
\text { ISO } 9324 \\
\text { JCSS }\end{array}$ & $\begin{array}{l}\text { Small } \\
\text { Small } \\
\text { Small }\end{array}$ & $\begin{array}{l}\text { Low } \\
\text { Some } \\
\text { Minor }\end{array}$ & $\begin{array}{l}\text { Normal } \\
\text { Moderate Moderate }\end{array}$ & $\begin{array}{l}\text { High } \\
\text { Great } \\
\text { Large }\end{array}$ \\
\hline $\begin{array}{l}\text { EN } 199050 \text { years } \\
\text { ISO } 9324 \text { life time } \\
\text { JCSS } 50 \text { years }\end{array}$ & $\begin{array}{c}- \\
1.3 \\
-\end{array}$ & $\begin{array}{l}3.3 \\
2.3 \\
2.5\end{array}$ & $\begin{array}{l}3.8 \\
3.1 \\
3.2\end{array}$ & $\begin{array}{l}4.2 \\
3.8 \\
3.5 \\
\end{array}$ \\
\hline $\begin{array}{l}\text { EN } 19901 \text { year } \\
\text { ISO } 93241 \text { year } \\
\text { JCSS } 1 \text { year }\end{array}$ & $\begin{array}{c}- \\
2.9 \\
-\end{array}$ & $\begin{array}{l}4.2 \\
3.5 \\
3.7 \\
\end{array}$ & $\begin{array}{l}4.7 \\
4.1 \\
4.2 \\
\end{array}$ & $\begin{array}{l}5.2 \\
4.7 \\
4.4 \\
\end{array}$ \\
\hline
\end{tabular}

ISO 9324) and 'moderate' relative safety costs after Arangio (2012)

\section{The task}

The task was presented and described from a mechanical aspect in Fig. 5. This presented a base for the assessment of reliability. To create the response surface, sets of several constant loads were applied in steady time periods. The assumed duration of each numerical experiment 
was also constant and equalled one year. Pairs of loads and periods due to the nonlinearity of the soft rock material (marl) response were analyzed for all possible combinations. A response surface was built on the basis of results of horizontal head pile displacements for sets of applied horizontal forces with values: $\mathbf{f}=\{0.8,1.6,3.2,4.0\}^{\mathrm{T}} \mathrm{MN}$. These forces were applied only on one half of the model, hence their total values are two times more. Durations of loading for the corresponding values of force were used as follows:

- $0.8 \mathrm{MN}-100,150,200$ days;

- $1.6 \mathrm{MN}-100,150,200$ days;

- $3.2 \mathrm{MN}-0,40,80$ days;

- $4.0 \mathrm{MN}-0,7,14$ days.

This selection was made based on histogram of Weibull's distributions for four bins refining ranges of their variability. In the next phase of the analysis, these distributions were used to generate random variables of periods. Each period was scaled proprotionally to to reach a one year in total sum. For example, sets of periods before scaling up to a full year are: $\{100,100,0,0\}$ days, $\{150,200,0,0\}$ days, $\{200,150,80,7\}$ days. The final set of computed data had $N=1944$ numerical experiments, each with 4 results of a horizontal pile head displacement. The number of calculations was solved by using the procedure written in Python. The script was automatically generated on outstanding server (SUN 1000) in Wrocław Supercomputing Computing Centrer in internal Abaqus files format (INP - input file). All calculations were carried out in the program Abaqus 6.9. The results were filtered for only the maximum pile horizontal displacement after each loading stage and they were collected by using procedures also written in Python language. Resulting files were in approximated size $12 \mathrm{MB}$ each and time consumption for calculated single subtask was about $310 \mathrm{sec}$. They were held and filtered only by network access without direct uploading. Examples of the results obtained from the calculations are presented in Fig. 7.

a)

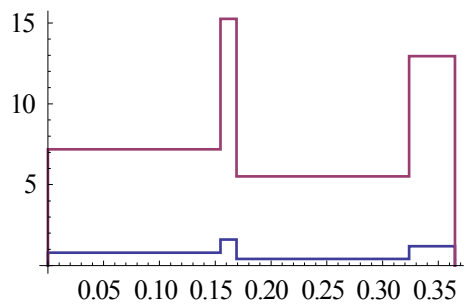

c)

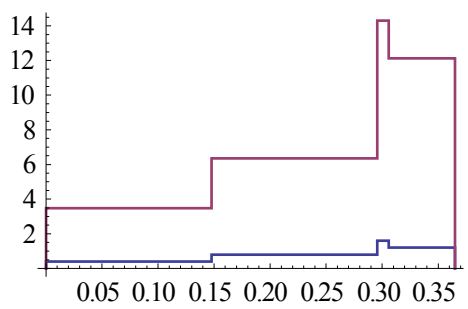

b)

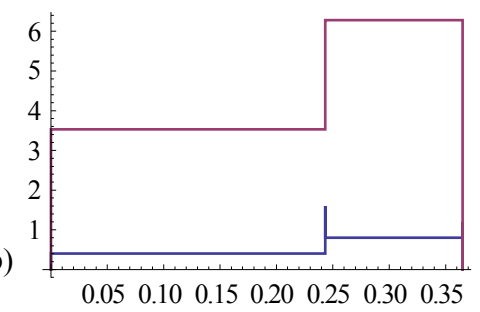

d)

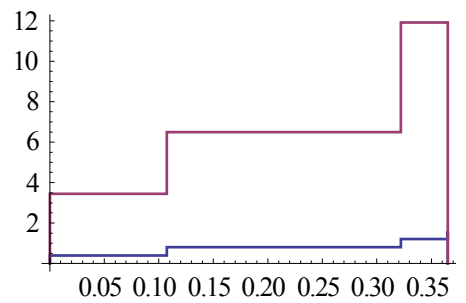

Fig. 7. Examples of results from Abaqus calculations; blue lines - values of horizontal forces [MN]; red lines - maximal horizontal displacement of pile $d[\mathrm{~mm}]$ in period of a force influences for sets: a) $\mathrm{Nr} 1000,\{1.6,4.0,0.8,3.2\} \mathrm{MN}$; b) $\mathrm{Nr} 1307,\{0.8,6.4,1.6,3.2\} \mathrm{MN}$; c) $\mathrm{Nr} 103,\{0.8,1.6,4.0,3.2\} \mathrm{MN}$;

d) $\mathrm{Nr} 505\{0.8,1.6,3.2,4.0\} \mathrm{MN}$. Vertical axes have two scales the one in [mm] for displacements and a the second in $\mathrm{MN}$ for forces, horizontal axes are in day times $10^{-2}$ 
For determination of the response surface, after establishing a direct link between the magnitude of the displacement in current end of load step and:

1. last step result;

2. current time of step;

3. current load.

This connection was used to construct hierarhical - similar to a row framework of wavelet neural network and the similar scheme of a classical neural network. Those are presented in Fig. $6 \mathrm{~b}$. The optimal number of wavelons and neurons was determined by using a test procedure for errors defined as follow:

$$
s_{j}=\frac{1}{N} \sqrt{\sum_{i=1}^{N}\left(d_{j, i}-\widetilde{d_{j, i}}\right)^{2}}, j=1 . .4
$$

where: $N=1944$ is the number of numerical experiments; $s_{j}$ denotes the error of aproximation by tested network in the spaces all calculated causes for each $j$ load periods $(j=1 . .4)-$ steps of an experiment; $d_{j, i}$ are results of calculations and $\widetilde{d_{j, i}}$ are matching results by one of the following networks: neural network (NN) with an activation function of neurons as hyperbolic tangent. In cases of wavelon neural networks (WNN) Gaussian (12) and Morlet (13) functions were used respectively. Structures of each tested network (WNN and NN) are showed in Fig. 6b. The results of the error calculations are presented in Fig. 8. In respect to these results, the following reliability calculations used the WNN with only Gaussian activation functions (12) and with the number wavelons for networks (WN1..WN4 Fig. 6b) were in range [25;35] depend on step.

a)

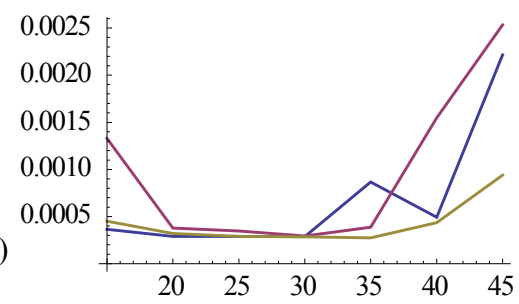

c)

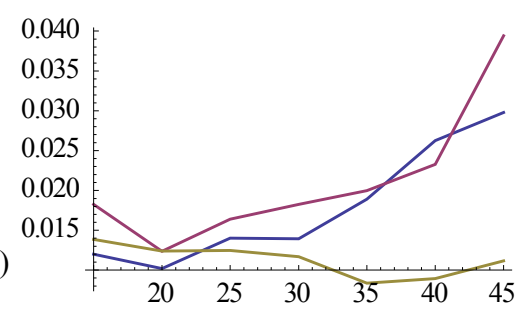

b)

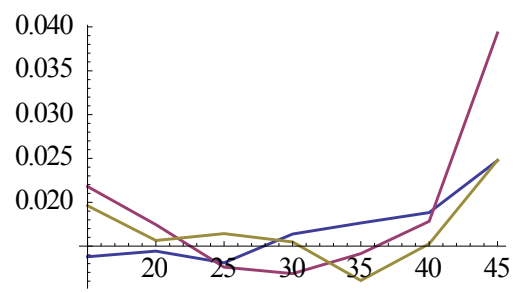

d)

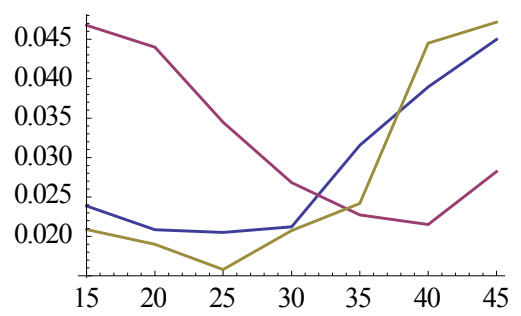

Fig. 8 Error matching results for network $\mathrm{NN}$ and $\mathrm{WNN}$ for a wide spectrum of neuron or wavelon numbers:

a) for the first load; b) for the second load step; c) for the third load step; d) for the fourth load step.

The horizontal axis is a number of neurons/wavelons in each layer of the network (WN1 .. WN4) and the vertical axis describes error (14). The colors mean: blue-NN with hyperbolic activation function, brown WNN Gaussian activation function and red WNN Morlet activation function 
The analysis considered a number of limits for a $\operatorname{HDP}$ as $\mathbf{d}_{\max }=\{15,20,25,30\}^{\mathrm{T}} \mathrm{mm}$, which are usually used as servicable limit state in various types of structures and representing typical restrictions. Weibull's probability distribution was used to generate random periods in the ninth variants described by the coefficients listed in Table 3 by coefficients of shape and scale and graphically illustrated in Fig. 9.

The procedure had three steps:

- Creation of histogram for random times in four categories corresponding to force intervals with constant medianas from $\mathbf{f}$.

- On random times and forces from collection $\mathbf{f}$ were conducted parallel permutations to set 24 possibilities.

- One set with a discrete uniform distribution has been drawn from this data set $[1 ; 24]$ - the only one possible set in an year.

The result was a value of HDP in four stages on the previous one set of $\mathbf{f}, \mathbf{t}$ from WNN (Fig.6b) with Gaussian activation function for wavelons. Calculations of reablility were made by using procedure of Monte Carlo. The pseudo-random number generator on the standard algorithm ExtendedCA was used in both cases. All functions were built in Mathematica based language with optimalisaton of the code. The scheme was repeated $10^{5}$ times, all results obtained from each step were categorized after limits $\mathbf{d}_{\max }$. and presented in Fig. 9 a2,b2,c2.

TABLE 3

Parameters of the Weibull's PDF $\left(\alpha, \beta_{1}\right)$ : average values and variances for all considered distributions in the reliability task

\begin{tabular}{|c|c|c|c|c|}
\hline \hline Figure & $\boldsymbol{\alpha}$ shape parameter & $\boldsymbol{\beta}_{\mathbf{1}}$ scale parameter & Average & Variance \\
\hline & 1.50 & 1.50 & 1.354 & 0.8453 \\
Fig. 9.a2 & 1.50 & 1.75 & 1.580 & 1.151 \\
& 1.50 & 2.00 & 1.805 & 1.503 \\
\hline & 1.75 & 1.50 & 1.336 & 0.6207 \\
Fig. 9.b2 & 1.75 & 1.75 & 1.558 & 0.8449 \\
& 1.75 & 2.00 & 1.781 & 1.103 \\
\hline & 2.00 & 1.50 & 1.329 & 0.4828 \\
Fig. 9.c2 & 2.00 & 1.75 & 1.551 & 0.6572 \\
& 2.00 & 2.00 & 1.772 & 0.8584 \\
\hline
\end{tabular}

We selected to present results obtained from reliability calculations based of WNN, coressponding to shapes of Weibull's distributions in three rows in Fig. 9.

The effects of changing of distribution parameters during a life time are reflected on the level of safety. This conclusion is clearly illustrated in Figure 9 , points: a1, b1 and c1 where for limitation HDP equals $20 \mathrm{~mm}$ the value of safety index $\beta$ has range from 1.5 to more than 6.2 and directly depends on coefficients of scale and shape of distribution. The form of probability distributions is jointed with system of collecting current data from monitoring system, especially in bridges and wind towers. 
a1)

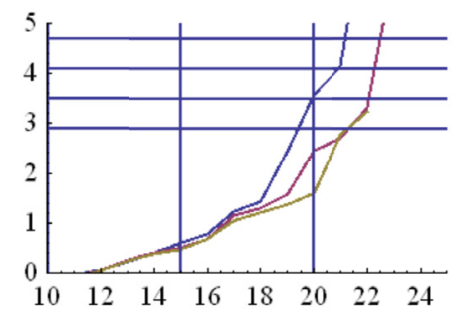

b1)

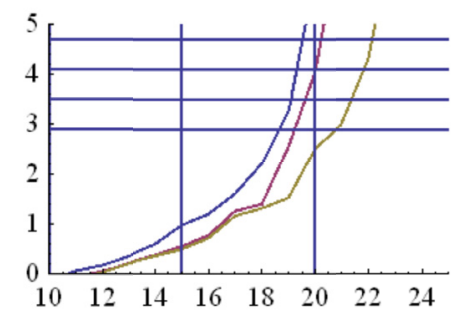

c1)

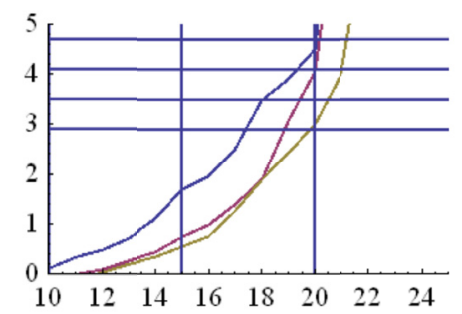

a2)

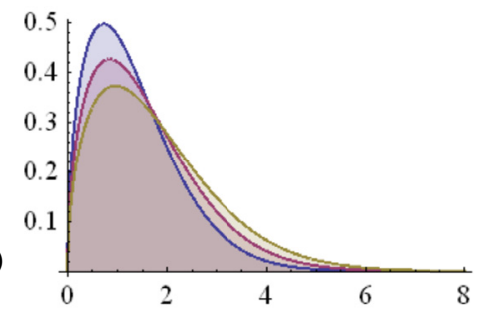

b2)

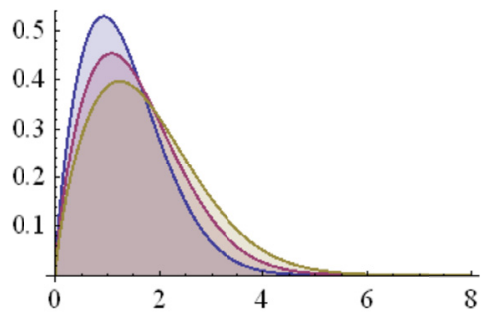

c2)

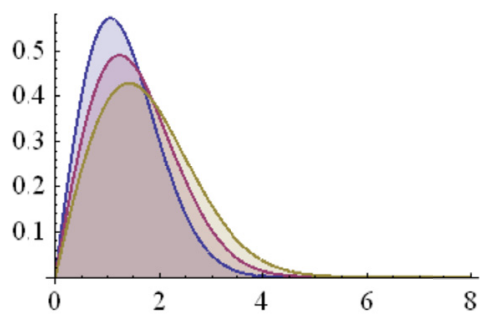

Fig. 9 The results of the probability calculations. Left side a1,b1,c1: vertical axis is safety index $\beta$, horizontal axis displacement of the pile head [mm], horizontal blue lines indicate the values of the threshold according to ISO 9324 for 1 year lifetime of construction. The right side a2,b2,c2 are the corresponding charts PDF where the vertical axis is the probability and the horizontal force [MN].

A colour blue is for coefficient $\beta_{1}=1.50$, a color red for the coefficient $\beta_{1}=1.75$, a color brown is the coefficient $\beta_{1}=2.00$. a1), a2 The coefficient $\alpha=1.50, \mathrm{~b} 1$ ) b2) $\alpha=1.75$, c1) c2) $\alpha=2.00$

\section{Conclusion}

The model was constructed using a number of simplifications such as: skipping displacement connected with a pile construction technology, a contact between pile and the soft rock was replaced by a fixed connection, only steady state was analyzed, that forces were immediately attached, values of forces are in limited collection, four periods were analyzed and influences of environment as water content in marl were omitted. The most important simplification is that the two layered visco-plascitity model was used instead of Wellner's model, as it has less coefficients to be determined and the resulting calibration is sufficiently convenient to describe time effects in marl. The simplicity of task and model was designed to mitigate problems of modeling the phenomena that occurrs in the material of rheological properties. The wavelon network based on a structure similar to row was used for reliability calculations. This network proved to be the most efficient among tested networks. WNN was based on attribute that result of pile head displacement in each stage is assumed of a load and a period of actual and predecessor stages. The 
constraints of the standard, mentioned before, were used to limitation period and value of safety indexess in this aspect the unity of fault occurrences were examined in one year. The calculations were performed for a wide range of variables and different shapes of their random distributions. In case of prolongation of the time of use of support constructions founded in marl, designers have to recalculate using the latest statistical data newest PDF for values and periods of loads and thereto related new safety level. The WNN based on Gaussian wevelons function ordered in the similar to row framework was selected for the reliability calculations. This paper presets a way to make assessment of safety indicators for time dependent material, which is widely spread in European mountain regions, and for popular type of support construction when horizontal forces have important influence. The comparison bewteen the accuracy of the approximation based on wavelons neural network and neural networks showed the WNN to be a good alternative to description response surface in time dependent task in rock mechanics.

\section{Acknowledgements}

The authors are grateful to Wroclaw Networking and Supercomputing Center for granting access to the computing infrastructure especially to Abaqus and Mathematica.

\section{References}

Abaqus Analysis User's Manual 6.9. Dassault Systèmes Simulia Corp., Providence, RI, USA.

Arangio S., 2012. Reliability based approach for structural design andassessment: performance criteria and indicators incurrent European codes and guidelines. Int. J. Lifecycle Performance Engineering, Vol. 1, No. 1.

Bauer J., Puła W., 2000. Neural network supported response surface method with respect to reliability computations in geotechnics. Studia Geotechnica et Mechanica, 22(3-4), 103-115.

Bauer J., Kozubal J., Puła W., Wyjadłowski M., 2012. Application of HDMR method to reliability assessment of a single pile subjected to lateral load. Studia geotechnica and mechanica, 3, 37-52.

Bauer J., Kozubal J., Puła W., Wyjadłowski M., 2013. Influence of varying soil properties on evaluation of pile reliability under lateral loads. Journal of Civil Engineering and Management, 19(2), 272-284.

Bieniawski Z., 1989. Engineering Rock Mass Classifications. New York: Wiley.

Box G., Draper N., 1996. Empirical Model Building and Response Surface. J. Wiley \& Sons, New York.

Ditlevsen O., 1979. Narrow reliability bounds for structural systems. Journal of Structural Mechanics, 7(4), 453-472.

Engelund S., Rackwitz R., 1992., Experiences with experimental design schemes for failure surface estimation and reliability. Proc. 6th Speciality Conf. Probabilistic Mechanics and Structural and Geotechnical Reliability, Denver, 252-255.

Faravelli L., 1989. A response surface approach for reliability analysis. Journal of the Engineering Me-chanics Division, ASCE 115(12), 2763-2781.

Gaige W., Lihong G., Hong D., 2013. Wavelet neural network using multiple wavelet functions in target threat assessment. Hindawi Publishing Corporation The Scientific World Journal Volume 2013, Article ID 632437, 7 p. http:// dx.doi.org/10.1155/2013/632437 .

Ismael N., 1990. Behavior of laterally loaded bored piles in cemented sands. J. Geotech. Eng., ASCE, 116(11), 1678-1699. ISO 2394:2000. General principles on reliability of structures. International Standard.

Jakubowski J., 2011. Probabilistic stability analysis of a tunnel in a fracture zone. Arch. Min. Sci., Vol. 56, No 3, 405-413.

Jiang C., Zhao M., Hu Y., Zhou K., 2014. Reliability Analysis of Laterally Loaded Piles Using Improved Response Surface. Advances in Soil Dynamics and Foundation Engineering, 229-240.

Joint Committee on Structural Safety (JCSS) 2001. Diamantidis D. (Ed.): Probabilistic Assessment of Existing Structures, RILEM Publications, Bagneux-France. 
Kamruzzaman M., Leonard T., Lye M., 2008. Probabilistic Analysis of Laterally Loaded Pile-Soil System using Monte Carlo Simulation. Proceedings of the Eighth ISOPE Pacific/Asia Offshore Mechanics Symposium Bangkok, Thailand, 190-204.

Kozubal J., Puła W., Stach M., 2014. Reliability assessment of a single pile in unsaturated substrate under climate factors influence. XXIII R-S-P seminar, Theoretical Foundation of Civil Engineering (23RSP).

Kwaśniewski M., 2013. Recent advances in studies of the strength of rocks under true triaxial compression conditions. Arch. Min. Sci., Vol. 58, No 4, 1177-1200.

Majcherczyk T., Niedbalski Z. Kowalski M., 2012. 3D numerical modelling of road tunnel stability - The Laliki project. Arch. Min. Sci., Vol. 57, No 1, 61-78.

Marquardt D., 1962. An Algorithm for Least-Squares Estimation of Nonlinear Parameters Related Databases. Journal of the Society for Industrial and Applied Mathematics, 11(2), 431-441.

Nowakowski A., 2012. The law of effective stress for rocks in light of results of Laboratory experiments. Arch. Min. Sci., Vol. 57, No 4, 1027-1044.

Percival D., Walden A., 2000. Wavelet Methods for Time Series Analysis, Cambridge University Press.

Randolph M., 1981. The response of flexible piles to lateral loading. Geotechnique, 31(2), 247-259.

Reese L., Van Impe W., 2001. Single Piles and Pile Group under Lateral Loading. A. A. Balkema, Rotterdam, 463 p.

Reese L., Welch R., 1975. Later al loading of deep foundation in stiff clay. J. Geotech. Engrg. Div., ASCE, 101(7), 633-649.

Tomanovic Z., 2006. Rheological model of soft rock based on test on marl. Int. J. Mechanics of Time-Dependent Materials, Springer, 135-154.

Torno S, Toraño J., Menéndez M., Gent M., Velasco J., 2012. Mathematical and fuzzy logic models in prediction of geological and geomechanical properties of rock mass by excavation data on underground works. Journal of Civil Engineering and Management, 17(2), 197-206.

Veitch D., 2005. Wavelet Neural Networks and their application in the study of dynamical systems and Nonlinear Dynamics. Dissertation submitted for the MSc in Data Analysis, Department of Mathematics University of York UK.

Wallner M., 1983. Stability calculation concerning a room and pillar design in rock salt. International Congress for Geotechnics, Melbourne.

Zivaljevic S., Tomanovic Z., 2014. Experimental research of the effects of pre-consolidation on the time-dependent deformations - creep of marl. Mechanics of Time-Dependent Materials, in editor's qualify process. 